\title{
PENGELOLAAN ZAKAT PRODUKTIF DALAM UPAYA PENGENTASAN KEMISKINAN DI INDONESIA
}

\author{
Makhrus \\ Universitas Muhammadiyah Purwokerto, Email : makhrus.ahmadi@gmail.com
}

\begin{abstract}
ABSTRAK
Artikel ini membahas mengenai pengelolaan zakat produktif dan dampaknya dalam upaya pengentasan kemiskinan yang dilakukan oleh berbagai organisasi pengelola zakat di Indonesia. Urgensi pengelolaan zakat produktif telah diatur dalam Undang-Undang Nomor 23 Tahun 2011 tentang pengelolaan zakat. Selain itu, pengelolaan zakat produktif yang optimal dan profesional senantiasa akan memberikan solusi terhadap masalah utama dalam struktur penerima zakat (depan ashnaf) yakni fakir miskin. Secara paradigmatik zakat sebagai salah satu intrumen rukun Islam memiliki dampak ekonomi dan sosial yang signifikan dalam pengentasan kemiskinan, sehingga para penerima zakat terutama kaum miskin secara perlahan diberdayakan ke dalam berbagai sektor strategis yang pada akhirnya dapat menjadi donatur atau para muzakki baru. Organisasi pengelola zakat yang digambarkan dalam isi artikel ini secara terprogram meneluri masalah utama kaum miskin dengan membuat berbagai program pemberdayaan masyarakat ke dalam bersektor utama yakni pendidikan, sosial, kesehatan, dan kebencanaan. Sementara evaluasi untuk mengukur perkembangan zakat nasional yang dapat menjadi indikator dampak zakat terhadap kehidupan mustahik, kelembagaan organisasi zakat, dan peran pemerintah, maka di Indonesia telah tersusun Indeks Zakat Nasional.
\end{abstract}

Kata-kata kunci : Pengelolaan; Zakat Produktif; Kemiskinan

ABSTRACT

This article discusses the management of productive zakat and its impact in efforts to alleviate poverty carried out by various zakat management organizations in Indonesia. The urgency of managing productive zakat has been regulated in Law Number 23 of 2011 concerning the management of zakat. In addition, the optimal management of productive and professional zakat will always provide a solution to the main problem in the structure of zakat recipients (ashnaf) namely the poor. Paradigmatically zakat as one of the instruments of the pillars of Islam has a significant economic and social impact in alleviating poverty, so that the recipients of zakat, especially the poor, are slowly empowered into various strategic sectors which eventually can become donors (new muzakki). The zakat management organization described in the contents of this article programmatically spearheads the main problems of the poor by making various community empowerment programs into the main sector, namely education, social, health, and disaster. While the evaluation to measure the development of national zakat can be an indicator of the impact of zakat on the lives of mustahik, the organization of zakat organizations, and the role of the government, then in Indonesia a National Zakat Index has been arranged.

Keywords: Management; Productive Zakat; Poverty. 


\section{PENDAHULUAN}

Pengelolaan zakat di Indonesia semakin menujukkan perkembangan yang signifikan. Hal tersebut ditandai dengan bertambahnya lembaga pengelola zakat resmi berbadan hukum yang didukung oleh kesadaran masyarakat untuk menunaikan zakat secara kelembagaan. Selain itu, adanya upaya negara dalam berbagai regulasi dan kebijakan terus dilakukan untuk menjadikan zakat sebagai instrumen ekonomi dengan adanya Undang-Undang No. 23 Tahun 2011 tentang Pengelolaan Zakat. Maka, hadirnya peran negara dalam upaya peningkatan pengelolaan zakat menjadi salah satu indikator bahwa negara tidak abai terhadap kepetingan umat, khususnya umat Islam di Indonesia.

Salah satu faktor yang mendorong mengoptimalkan pengelolaan zakat di Indonesia didasarkan pada potensi zakat yang sangat besar dan belum tergali secara maksimal. Berdasarkan data Outlook Zakat 2017 menyebutkan bahwa pada tahun 2015 potensi zakat di Indonesia mencapai 286 triliun. Sementara pengumpulan zakat di Indonesia berdasarkan data Statistik Zakat Naisonal 2017 menunjukkan bahwa total penghimpunan zakat yang dilakukan oleh Lembaga Amil Zakat (LAZ) dan Badan Amil Zakat Nasional (BAZNAS) pusat hingga Kabupataten/Kota mencapai Rp. 6.224.371.269.471 rupiah, sementara hasil penyalurannya mencapai Rp. 4.860.155.324.445. Dari total pengumpulan dan pendistribusian zakat di atas, maka masing-masing organisasi pengelola zakat yakni BAZNAS dan Lembaga Amil Zakat (LAZ) nasional sebagian besar pendistribusiannya dialokasikan pihak yang berhak menerima zakat (depalan ashnaf), terutama fakir miskin.

Potensi dan dukungan berbagai stakeholders dalam pengelolaan zakat di Indonesia senantiasa memberikan dampak signifikan dalam aspek pengelolaaan (manajemen) secara kelembagaan. Maka, dalam konteks pengelolaan zakat mengakibatkan semakin berkurangnya pengumpulan dan pengelolaan zakat secara musiman, sebagaimana banyak dijumpai pada saat jelang bulan suci Ramadhan dan hari raya Idhul Fitri dan Idhul Adha. Oleh sebab itu, badan dan lembaga zakat semakin bergerak secara kreatif, baik dengan menghimpun dana dari masyarakat yang tidak hanya mengandalkan pola konvensional dengan menunggu datangnya donatur, namun dilakukan dengan memanfaatkan sosialisasi lain dengan cara 
jemput bola seperti: direct mail, website, SMS, BBM, WhatsApp dan media sosial sebagaimana telah dilakukan oleh komunitas filantropi Islam berbasis media social (Makhrus, 2018: 365).

Sementara realisasi zakat dalam sudut pandang penerima zakat (mustahiq), kelompok fakir dan miskin masih menjadi kelompok dominan dan harus segera diberdayakan. Berdasarkan data Badan Pusat Statistik (BPS) bulan Maret 2018 terdapat 25, 95 juta orang penduduk miskin. Faktor yang mempengaruhi tingkat kemiskinan antara 2017 sampai dengan Maret 2018 tersebut yakni inflasi, rata-rata pengeluaran per kapita untuk rumah tangga, bantuan tunai pemerintah, dan nilai tukar rupiah. Sekalipun, ketingkat kemiskinan terdapat penurunan pada Maret 2018 dibandingkan dengan periode September 2017 yang mencapai 26,58 juta orang atau ada penurun sebesar 1,19 juta orang, namun hal ini tidak serta merta persoalan kemiskinan di Indonesia selesai. Apalagi, untuk mengukur kemiskinan, BPS menggunakan konsep kemampuan untuk memenuhi kebutuhan dasar (basic needs approach), oleh sebab itu, dalam sudut pandang pengukuran kemiskinan, maka kemiskinan dipandang sebagai ketidakmampuan dari sisi ekonomi untuk memenuhi kebutuhan dasar makanan dan bukan makanan yang diukur dari sisi pengeluaran, sehingga penduduk miskin adalah penduduk yang memiliki rata-rata pengeluaran perkapita perbulan dibawah garis kemiskinan (BPS, 2018).

Dalam cetak biru pengembangan zakat Indonesia 2011-2025 yang dikeluarkan oleh Forum Zakat (FOZ) yang mendorong adanya pemetaan kaum mustahik, khususnya fakir dan miskin menjadi sebuah konsensus yang disetujui organisasi pengelola zakat. Maka, dengan adanya peta mustahik ini akan memudahkan dalam pendistribusian zakat secara menyeluruh, tanpa adanya tumpang tindih pemberian program antar pengelola zakat yang satu dengan yang lain. Maka, adanya peta mustahik pada prinsipnya tidak hanya memudahkan pendistribusian zakat, melainkan juga akan memudahkan dalam pengumpulan zakat.

Manajemen institusi pengelola zakat yang profesional akan menjadi salah satu indikator suksesnya pengelolaan zakat secara kelembagaan. Sebab, dengan adanya manajemen pengumpulan dana (funding) dan pendayagunaan (empowering) yang kredibel dan akuntabel pada organisasi pengelola zakat senantiasa akan menyebabkan seluruh program akan berjalan secara maksimal, mulai tahap perencanaan program sampai 
dengan tindak lanjut pelaksanaan program (follow up). Selain itu, pemberdayaan masyarakat yang dilaksanakan oleh institusi pengelola zakat harus terus diupayakan, apalagi pemberdayaan masyarakat pada pengelolaan zakat terbagi atas dua hal yakni, pemberdayaan terhadap muzakki agar senantiasa menyalurkan zakat kepada lembaga, sementara pemberdayaan masyarakat terhadap mustahik dan berkaitan efek penerimaan terhadap program pendayagunaan.

Guna memberikan dampak yang lebih optimal dalam penggalian potensi dan realisasi pengelolaan zakat, maka perlu adanya kajian dan penelitian mengenai manajemen zakat yang dilakukan secara kelembagaan, sehingga mampu memberikan evaluasi dan saran agar pengelolaan zakat dalam jangka panjang dapat berdampak sistemik terhadap kehidupan masyarakat yang ditandai dengan terciptanya kemandirian dan kesejahteran masyarakat yang menerima program zakat.

\section{PEMBAHASAN}

Pengelolaan zakat di Indonesia berdasarkan Undang Undang Nomor 23 Tahun 2011 tentang Pengelolaan Zakat hanya terdapat dua institusi pengelola zakat yakni Badan Amil Zakat Nasional (BAZNAS) dan Lembaga Amil Zakat (LAZ). Adanya Undang Undang Nomor 23 Tahun 2011 ini memberikan jalan terang mengenai pentingnya pengelolaan zakat secara maksimal, serta adanya keterlibatan negara dalam memberikan peran dan kontribusi dalam mengoptimalkan pengelolaan zakat di Indonesia. Zakat secara bahasa berarti suci, tumbuh, berkah dan terpuji. Sedangkan secara istilah suatu ibadah wajib yang dilaksanakan dengan memberikan sejumlah kadar tertentu dari harta sendiri kepada orang yang berhak menerima sesuai dengan ketentuan syariat Islam (Muhammadiyah, 20014: 1-2), sehingga zakat hanya bisa direalisasikan dengan menyerahkan harta yang berwujud, bukan didasarkan pada nilai manfaat, seperti memberikan hak menempati rumah bagi orang miskin sebagai zakat (Qardhawi, tt: 125).

Secara kelembagaan organisasi pengelola zakat di Indonesia setidaknya terbagi menjadi empat bagian, yakni: pertama, organisasi pengelola zakat semi-struktural, adalah organisasi pengelola zakat yang secara kelembagaan dan sejarah berdirinya masih berafialasi dengan pemerintah, organisasi ini diwakili oleh Badan Amil Zakat Nasional 
(BAZNAS) akibat berlakunya UU Nomor 23 tahun 2011 Pengelolaan Zakat, serta secara kelembagaan Badan Amil Zakat Daerah (BAZDA) pada tingkat Provinsi atau Kabupaten/Kota kemudian turut berganti nama menjadi BAZNAS. Kedua, lembaga zakat, adalah lembaga zakat yang sejak awal berdirinya atau dalam perkembangannya telah dijadikan lembaga zakat yang tidak memiliki afilisasi tertentu dengan organisasi masyarakat tertentu, seperti, Dompet Dhuafa, Rumah Zakat, dan lainnya. Ketiga, organisasi berbasis organisasi masyarakat (Ormas) keagamaan, adalah organisasi pengelola zakat yang secara kelembagaan berafiliasi dengan Ormas keagamaan tertentu, seperti Muhammadiyah dengan LAZISMU, Nahdhatul Ulama dengan NU Care-LAZISNU, Al Irsyad dengan LAZIS Al Irsyad, dan sebagainya. Keempat, berbasis yayasan, adalah organisasi pengelola zakat yang secara kelembagaan berafiliasi dengan yayasan tertentu, seperti Darut Tauhid dengan DT Peduli, Yayasan BSM Umat dengan BSMU, dan sebagainya.

Pasca berlakunya Undang-Undang (UU) Nomor 23 tahun 2011 tentang Pengelolaan Zakat, organisasi pengelola zakat hanya terbagi menjadi dua bagian yakni: pertama, BAZNAS sebagai pengelola zakat nasional yang dibentuk pemerintah. Kedua, Lembaga Amil Zakat (LAZ) sebagai organisasi zakat yang dibentuk oleh masyarakat yang memiliki tugas membantu pengumpulan, pendistribusian, dan pendayagunaan zakat. Selain itu, dalam Undang-Undang Nomor 23 tahun 2011 Pasal 27 Poin 1 dan 2 juga menjelaskan bahwa zakat dapat didayagunakan untuk usaha produktif dalam rangka penanganan fakir miskin dan peningkatan kualitas umat sepanjang kebutuhan dasar mustahik dapat terpenuhi. Dalam penjelasan Undang-Undang tersebut juga dijelaskan bahwa usaha produktif yang dimaksud yakni usaha yang dapat meningkatkan pendapatan, taraf hidup, dan kesejahteraan masyarakat. Sementara kebutuhan dasar mustahik tersebut melliputi pangan, sandang, perumahan, pendidikan, dan kesehatan.

Kemiskinan adalah keterbatasan yang sandang oleh seseorang, keluarga, komunitas, dan negara yang menyebabkan ketidaknyamanan dalam kehidupan, terancamnya penegakan hukum dan keadilan, hingga hilagnya masa depan bangsa dan negara (Suwandi, 2015: 80). Sementara Badan Pusat Statistik (BPS) memberikan pengertian ketidakmampuan dari sisi ekonomi untuk memenuhi kebutuhan dasar makanan dan bukan 
makanan yang diukur dari sisi pengeluaran, sehingga penduduk miskin adalah penduduk yang memiliki rata-rata pengeluaran per kapita perbulan dibawah garis kemiskinan (BPS, 2018). Kemiskinan juga dikaitkan dengan adanya keterbatasan terhadap hak-hak sosial, ekonomi, dan politik, sehingga menyebabkan kerentanan, keterpurukan, dan ketidakberdayaan. Kemiskinan menurut Wold Bank (2000) mendefinisikan sebagai bentuk kehilangan kesejahteraan. Sedangkan dalam Undang-Undang Nomor 13 Tahun 2011 tentang Penanganan Fakir Miskin, pengertian fakir miskin adalah orang yang sama sekali tidak mempunyai sumber mata pencaharian dan atau mempunyai sumber mata pencaharian tetapi tidak mempunyai kemampuan memenuhi kebutuhan dasar yang layak bagi kehidupan dirinya dan atau keluarganya.

Kemiskinan bila ditinjau dari penyebabnya hampir sebagian besar para pakar, termasuk Irfan Syauqi Beik dan Laily Dwi Arsyianti (2016) menyebutkan penyebab kemisninan disebabkan oleh empat faktor yakni: pertama, faktor individu, kemiskinan terjadi dikarenakan pribadinya, seperti, terjadinya cacat permanen maupun cacat secat dari lahir, sehingga mengalami keterbatasan dalam mengakses pekerjaan produktif untuk meningkatkan kualitas hidupnya. Kedua, faktor sosial, kemiskinan terjadi dikarenakan adanya diskriminasi sosial, seperti minimnya akses, konflik, dan minimnya infrastrukur. Ketiga, faktor kultural, kemiskinan terjadi karena adanya budaya negatif masyarakat atau lingkungannya, seperti adanya budaya malas bekerja, suka nongkrong, dan hal-hal tidak produktif lainnya, sehingga hal ini disebut sebagai kemiskinan kultural. Keempat, faktor struktural, kemiskinan terjadi karena adanya akibat ketidakadilan sistem ekonomi. Sedangkan berkaitan kemiskinan Bank dunia (2006) membagi dimensi kemiskinan ke dalam empat kelompok, yakni: lack of opportunity, low capabilities, loe leve security, dan low capacity.

Berdasarkan penyebab terjadinya kemiskinan tersebut di atas, maka berbagai formulasi dilakukan oleh pemerintah melalui kebijakan struktural dengan penyediaan berbagai regulasi, paket kebijakan, mendorong investasi, hinngga menyediakan akses lapangan pekerjaan. Sementara di sisi lain, berbagai komunitas masyarakat terus mengorganisir diri untuk dapat saling berdaya secara kolektif melalui modal sosial maupun adanya instrumen keagamaan yang dimiliki, seperti wakaf dan zakat. Namun, persoalan kemiskinan tetap saja menjadi persoalan yang terus senantiasa 
membutuhkan pemecahan serius dan sistemik.

Upaya menjadikan zakat sebagai salah satu instrumen penanganan kemiskinan terus diinisiasi dan dilakukan oleh organisasi pengelola zakat di Indonesia. Hal tersebut ditandai dengan adanya berbagai program pemberdayaan berbasis zakat yang secara kreatif dan edukatif terus dilakukan guna memberikan dampak produktif terhadap pendistribusian zakat. Biasanya, program yang dilakukan dalam pengelolaan zakat produktif berupa pemberdayaan masyarakat kegiatan usaha produktif, baik berupa perdagangan, pertanian, perikanan, dan berbagai sektor produktif lainnya yang dapat meningkatkan produktifitas dan penghasilan para mustahik, sehingga keluar dari lingkaran kemiksinan yang pada akhirnya menjadi seorang muzaki baru.

Pengalaman BAZNAS sebagai organisasi pengelola zakat yang dibentuk pemerintah terus mendorong pembayaran zakat para Aparatur Sipil Negara (ASN) dan mendistribusikannya dalam berbagai sektor usaha produktif. Keberadaan BAZNAS sebagai regulator dan operator zakat nasional tentu saja memiliki peran strategis dalam pengelolaan zakat, dikarenakan adanya dukungan penuh pemerintah terhadap BAZNAS operasionalisasi kelembagaannya. Dalam pendistribusian zakat yang telah dikumpulkan oleh BAZNAS terbagi atas tiga sektor utama yakni : pertama, sektor ekonomi yang meliputi zakat community development, BAZNAS microfinance, pemberdayaan ekonomi, dan pemberdayaan peternak. Kedua, sektor sosial, yang meliputi program layanan aktif BAZNAS, BAZNAS tanggap bencana, rumah sehat BAZNAS, sekolah cendekia BAZNAS, lembaga beasiswa BAZNAS. Ketiga, dakwah dan akvokasi, yang meliputi program muallaf center BAZNAS dan pusat kajian strategis.

Fokus pogram yang dilakukan BAZNAS secara umum menekankan pada persoalan mendasar para mustahik yakni ekonomi dan sosial. Misalnya, pada program zakat community development, BAZNAS telah mengintegrasikan aspek-aspek dakwah, ekonomi, pendidikan, kesehatan, dan kemanusiaan dalam satu program yang mendorong pemberdayaan zakat berbasis sumber daya lokal hingga pemberdayaan fasilitator/kader lokal. Maka, dengan adanya pola integratif ini sebaran program menjadi luas dan memiliki dampak signifikan dikarenakan berbasis kearifan lokal. Selain itu, adanya keberadaan Pusat Kajian Strategis (Puskas) BAZNAS sebagai lembaga pusat kajian dan riset turut memberi sumbangsih 
tersendiri dalam mengukur, merancang, dan mengevaluasi berbagai kegiatan pengelolaan zakat yang dilakukan oleh BAZNAS maupun LAZ secara nasional.

Keberadaan LAZ sebagai organisasi pengelola zakat yang diiniasi oleh masyarakat juga turut memberikan andil besar dalam mendorong pengumpulan dan pendistribusian zakat secara maksimal. Berdasarkan data Pengelolaan Informasi dan Dokumentasi (PID) BAZNAS tahun 2019 telah terdapat 19 LAZ nasional, 9 LAZ provinsi, dan 25 LAZ kabupaten/ kota. Adanya jumlah yang LAZ yang cukup banyak ini harusnya penggalian potensi zakat di Indonesia yang besar dapat optimalkan dengan pendistribusian zakat maksimal. Persoalan yang seringkali dihadapi oleh LAZ adalah berkaitan dengan minimnya sumber daya manusia yang terbatas dan peta muzakki dan mustahik belum berintegrasi satu sama lain, sehingga dalam praktik pengelolaan programnya terkesan tumbang tindih, baik pada muzakki selaku donator maupun mustahik sebagai penerima program. Namun, berbagai sumbatan keterbatasan tersebut belakangan ini mulai terurai yakni dengan adanya Forum Zakat (FOZ) yang menjadi wadah koordinatif organisasi pengelola zaka nasional.

Dompet Dhuafa sebagai salah satu LAZ nasional mendistribusikan zakat yang telah dikumpulkan ke dalam berbagai sektor, yakni: kesehatan, pendidikan, ekonomi, pengembangan sosial, dan advokasi. Secara khusus Dompet Dhuafa kini sedang mengusung kampanye "jangan takut berzakat" mengorganisir penenun batik lurik di Klaten, petani kopi gayo di Aceh, hingga pemberian beasiswa dengan nama program SMART Cendekia. Ternyata, hal serupa juga dilakukan oleh Rumah Zakat yang mengelola pengumpulan zakatnya ke dalam empat rumpun utama program pemberdayaan masyarakat yakni: senyum juara (pendidikan), senyum sehat (kesehatan), senyum mandiri (pemberdayaan ekonomi), dan senyum lestari (inisiatif kelestarian lingkungan). Jaringan Rumah Zakat yang telah membuka kantor cabang di beberapa daerah dan berbagai mitra jejaring menyebabkan Rumah Zakat secara kelembagaan mampu menjaring donatur dari berbagai sektor, sementara salah program pemberdayaan masyarakat yang cukup unik yang dilakukan oleh Rumah Zakat yakni Klinik Pratama Rumah Bersalin Gratis (RBG) yang tersebar di beberapa kota besar di Indonesia. Adanya klinik RBG ini memberikan pelayanan pemeriksanaan hingga pemberian obat secara gratis. 
LAZ nasional lainnya yang turut mengelola zakat secara produktif adalah Yayasan Pos Keadilan Peduli Ummat (PKPU) yang lahir pada tahun 2001. Program yang dilakukan oleh PKPU tetap memfokuskan pada bidang ekonomi, kesehatan, pendidikan, dan tanggap darurat. Kini, PKPU yang telah mem-branding diri dengan nama PKPU Human Inisiative atas kinerja yang telah dilakukan mendapakan pengakuan internasional yakni terdaftar di Perserikatan Bangsa Bangsa (PBB) sebagai Non Government Organization (NGO) sebagai special consultative status with the economic social council pada tahun 2006. Selain itu, adapula Inisiatif Zakat Indonesia (IZI) yang lahir pada tahun 2014 dengan memisahkan diri dari lembaga induknya Yayasan Pos Keadilan Peduli Ummat (PKPU). Program yang dilakukan oleh IZI sebenarnya hampir sama dengan organisasi pengelola zakat lainnya. Adapun program yang dilakukan oleh IZI adalah IZI to success, IZI to smart, IZ to fit. Ketiga program tersebut dilakukan IZI untuk melakukan pemberdayaan ekonomi, pendidikan, penanganan kesehatan para mustahik.

Pengelolaan zakat yang dilakukan oleh ormas keagamaaan dilakukan oleh LAZISMU yang merupakan lembaga zakat milik Muhamadiyah. Secara kelembagaan LAZISMU tersebar di seluruh Indonesia bersamaan keberadaan cabang dan ranting Muhammadiyah. LAZISMU lahir pada tahun 2002 dan membagi programnnya menjadi lima pilar, yakni pendidikan (save our school, trensains, beasiswa sang surya, beasiswa mentari, dan lainnya), kesehatan (klinik apung Said Tuhuleley dan end TB), ekonomi (tani bangkit, 1000 UMKM, pemberdayaan masyarakat madani, dan lainnya), dakwah (dai mandiri, back to masjid, dan pemberdayaan muallaf), sosial keagaamaan (Muhammadiyah Aid, Fidyah, dan lainnya). Sementara organisasi pengelelola zakat berbasis ormas keagamaan adalah NU Care-LAZISNU hampir sama dengan LAZISMU, dimana NU CareLAZISNU terikat dengan organisasi induknya yakni Nahdhatul Ulama, sehingga keberadaan NU Care-LAZISNU melekat bersamaan dengan keberadaan Nahdhatul Ulama di Indonesia. Adapun program yang dilakukan oleh NU Care-LAZISNU terbagi atas tujuh program yakni pendidikan, kesehatan, ekonomi, bencana, kemanusiaan, ramadan, dan kurban.

Guna memberikan dampak pengelolaan dan pendistribusian zakat Puskas BAZNAS menyusun Indeks Zakat Nasional (IZN) yang merupakan 
indeks komposit dengan tujuan mengukur perkembangan kondisi perzakatan nasional. Indikator IZN untuk memberikan gambaran zakat terhadap kesejahteraan mustahik, kelembagaan institusi zakat, partipasi masyarakat, dan dukungan pemerintah. Oleh sebab itu, komponen dalam pembentuk IZN sebagai berikut :

Tabel 1 : Komponen Pembentuk IZN

\begin{tabular}{ccc}
\hline Dimensi & Indikator & Variabel \\
\hline Makro & Regulasi & Regulasi \\
& Database lembaga zakat & Database jumlah lembaga zakat resmi, \\
& muzakki, dan mustahik \\
& Rasio muzakki individu \\
Mikro & Rasio muzakki badan \\
& Kelembagaan & Penghimpunan \\
& & Pengelolaan \\
& Penyaluran \\
& Pelaporan \\
& Dampak zakat & Pesejahteraan material dan spiritual (indek \\
& kesejteraan CIBEST) \\
& & Kemandirian \\
\hline
\end{tabular}

Sumber : Puskas Baznas, 2016: 13

Berbagai program yang telah dilaksanakan oleh BAZNAS dan LAZ sebagaimana telah disampaikan pada pembahasan sebelumnya mencapai Rp. 6.224.371.269.471 rupiah, sementara hasil penyalurannya mencapai Rp.4.860.155.324.445. Tentu saja, hal yang patut menjadi tolak ukur dalam konteks ini, bukan seberapa besar dana yang terkumpul dan tersalurkan, namun seberapa banyak mustahik yang terberdayakan melalui berbagai program yang dilakukan oleh organisasi pengelola zakat. Berdasarkan laporan Evaluasi Kinerja Perzakatan Nasional yang dikeluarkan oleh Puskas BAZNAS tahun 2017 berdasarkan hasil penghitungan Indeks Zakat Nasional (IZN) sebagai sebuah alat ukur kinerja lembaga-lembaga zakat menunjukkan bahwa secara agregat untuk 28 provinsi menujukkan sebanyak 7 (tujuh) yang menunjukkan kinerja baik, yakni: Aceh, Jawa Timur, Nusa tenggara Barat, Banten, Kalimantan Tengah, Selawesi Tenggara, dan Sumatera Barat, sementara sisanya berkatagori cukup baik dan kurang baik.

Penyusunan pembentuk IZN menetapkan sebuah pedoman yang menjadi konsep dasar dalam keseluruhan proses penyusunan indeks yang 
dibuat yang dikenal dengan istilah SMART (Spesific, Measurable, Applicable, Reliable, dan Timely), sementara dalam penghitungannya metode Multi Stage Weighted Index yang menggabungkan beberapan proses tahapan pembobotan yang telah diberikan pada tiap komponen penyusun indeks, sehingga pembobotan yang diberikan pada tiap komponen harus dilakukan secara bertahap bersifat prosedural (Puskas Baznas, 2016: 14).

Relasi antara pengelolaan zakat produktif dengan pengurangan tingkat kemiskinan menurut Irfan Syauqi Beik dan Laily Dwi Arsyianti dalam melihat suatu garis kemiskinan tidak hanya dilihat dari masalah materiil saja, namun aspek spiritual masuk dalam hal tersebut, kedunya menawarkan empat kuadran yang dapat menjadi bahan evalusi upaya pengentasan kemiskinan atau lebih sering kenal dengan model Center for Islamic Business and Economic Studies (CIBEST). Dalam model CIBEST membagi konsidi suatu rumah tangga atau keluarga ke dalam empat kelompok (quadran), yakni: pertama, suatu rumah tangga memiliki kemampuan dalam memenuhi kebutuhan spiritual dan material disebut dengan rumah tangga sejahtera. Kedua, suatu rumah tangga hanya mampu memenuhi kebutuhan spiritual saja disebut dengan konsidi kemiskinan material. Ketiga, suatu rumah tangga hanya mampu memenuhi kebutuhan material saja disebut dengan kelompok kemiskinan spiritual. Keempat, suatu rumah tangga tidak mampu memenuhi kedua kebutuhan tersebut, yaitu kebutuhan material dan spiritual, konsidi ini disebut dengan kelompok kemiskinan absolut (Beik dan arsyianti, 2015: 95).

Berkaitan dengan penyaluran zakat nasional berdasarkan Outlook Zakat Indonesia tahun 2018 menunjukkan bahwa terjadi peningkatan dan pengurangan penyaluran zakat yang dilakukan oleh organisasi pengelola zakat resmi antara tahun 2015 dengan 2016. Pada tahun 2015 bidang ekonomi penyalurannya sebanyak $15,01 \%$ pada tahun 2016 naik menjadi 18,30\%, bidang pendidikan tahun 2015 sebanyak 20,35\% pada tahun 2016 naik menjadi 31,28\%, bidang dakwah tahun 2015 sebanyak 14,87\% pada tahun 2016 naik menjadi 15,53\%, bidang kesehatan tahun 2015 sebanyak $8,50 \%$ pada tahun 2016 turun menjadi 8,39\%, kemudian, bidang sosial keagamaan tahun 2015 sebanyak 41,27\% pada tahun 2016 turun menjadi 26,51\%. Dari kelima sektor strategis tersebut di atas menunjukkan bahwa bidang sosial keagamaan mengalami penurunan drastis ketimbang bidang kesehatan. Artinya, bidang sosial keagamaan tidak lagi dijadikan skala 
prioritas dalam bidang penyaluran zakat, hal ini dikarenakan bidang sosial keagamaan berdasarkan penyaluran program telah banyak dilakukan organisasi sosial keagamaan yang mampu mengorganisir masyarakat dari berbagai sektor, sehingga lembaga zakat dapat berkonsentrasi kepada sektor lain yang lebih strategis.

Pendistribusian zakat oleh BAZNAS sebagaimana telah dilakukan BAZNAS Kabupaten Banyumas membagi program pendistribusian zakat menjadi dua bagian, yakni: pertama, zakat konsumtif yang berkaitan dengan kebutuhan jangka pendek mustahik. Kedua, zakat produktif diarahkan untuk memberikan kebutuhan jangka panjang para mustahik yang harapannya dapat memberi dampak sistemik pemberdayaan dalam berbagai usaha produktif yang dapat dilakukan para mustahik (Makhrus\&Utami, 2015: 179). Adapun tabel pendistribusian zakat di BAZNAS Kabupaten Banyumas sebagai berikut :

Tabel 1 : Pendisribusian zakat oleh BAZNAS

\begin{tabular}{cc}
\hline Konsumtif & Produktif \\
\hline $\begin{array}{c}\text { Fakir miskin, fisabilillah, ibnu sabil, } \\
\text { ghorimin, muallaf, sarana dan } \\
\text { prasarana kemaslahatan ummat, } \\
\text { kegiatan ilmiah, benah rumah, }\end{array}$ & $\begin{array}{c}\text { Modal usaha (hibah), modal usaha } \\
\text { (pinjaman/dana bergulir), modal } \\
\text { kelompok usaha kecil (hibah/bergulir), } \\
\text { pendidikan, pengobatan, dan bencana }\end{array}$ \\
\hline
\end{tabular}

Sumber : Makhrus\&Utami, 2015: 179

Bentuk pendayagunaan program oleh organisasi pengelola zakat baiknya lebih menekankan pada bentuk pendampingan secara massif dan efektif dengan pendekatan parcipatory rural appraisal (PRA). Metode ini cukup banyak dilakukan oleh LAZ, dimana pihak lembaga terlibat langsung kesuatu kawasan yang diindikasikan banyak kemiskinan atau yang hendak dilakukan sebagai pilot project program pemberdayaan. Misalnya, dalam proses pendampingan oleh Dompet Duafa Jogja terhadap masyararakat yang dibinanya cukup dibilang baik, sebab secara kelembagaan program yang dilaksanakan tidak saja terlaksananya program, melainkan juga berperannya pihak mitra kerjanya, hal tersebut terlihat dalam program Madrasah Ekonomi Dhuafa/Sakofa yang bekerja sama dengan BMT sebagai lembaga keuangan yang mencairkan dana program pemberdayaan (Makhrus, 2018: 73-74). Pemberdayaan masyarakat yang dilakukan oleh lembaga zakat secara keseluruhan menekankan pada 
terciptanya advokasi dalam setiap sistem pemberdayaan yang memiliki target jangka panjang. Adanya penggunaan pendekatan PRA sebagai teknik keterlibatan masyarakat dalam proses pemikiran selama perencanaan, pelaksanaan, pemantauan dan evaluasi selama program pemberdayaan masyarakat. Selama proses tersebut juga dibutuhkan prinsip dasar pendampingan, yakni: pertama, belajar dari masyarakat yang menekankan pada dari, oleh, dan untuk masyarakat. Kedua, pendamping sebagai fasilitator dan masyarakat sebagai pelaku. Ketiga, saling belajar saling berbagi pengalaman (Karsidi, 2009: 137-138).

\section{PENUTUP}

Pengelolaan zakat produktif yang dilakukan organisasi pengelola zakat di Indonesia secara umum didistribusikan dalam beberapa sektor seperti, pendidikan, ekonomi, dakwah, kesehatan, dan sosial keagamaan. Sementara upaya dalam pengentasan kemiskinan dilakukan dengan menyusun program pemberdayaan masyarakat berdasarkan kelima sektor di atas, meski sektor ekonomi dan pendidikan menjadi proritas utama dalam melakukan pemberdayaan masyarakat. Untuk pengukur efektifitas pelaksanaan program dan bentuk evaluasi program masing-masing organisasi pengelola zakat memiliki metode tersendiri, meski secara keseluruhan menunjukkan respon positif, mulai dari partipasi masyarakat, dukungan pemerintah, dan profesionalitas kelembagaan lembaga zakat.

\section{DAFTAR REFERENSI}

Beik, Irfan Syauqi, Laily Dwi Arsyianti, 2016. Ekonomi Pembangunan Syariah, Jakarta: RajaGrafindo Persada.

BAZNAS, Pusat Kajian Strategi. "Indeks Zakat Nasional." Jakarta: Puskas BAZNAS (2016).

"Outlook Zakat Indonesia 2018." Jakarta: Puskas BAZNAS. (2018).

"Evaluasi Kinerja Perzakatan Nasional" Jakarta: Puskas BAZNAS (2017)

Efendi, Mansur. "Pengelolaan Zakat Produktif Berwawasan Kewirausahaan Sosial dalam Pengentasan Kemiskinan Di Indonesia." Al-Ahkam: Jurnal Ilmu Syariah dan Hukum 2.1 (2017).

Forum Zakat. 2012. Cetak Biru Pengembangan Zakat Indonesia 2011-2025, Panduan Masa Depan Zakat Indonesia. Jakarta: Forum Zakat (FOZ). 
Makhrus "Social Media Based Islamic Philanthropy To Develop Philanthropy Awareness In Indonesia." 2018 3rd International Conference on Education, Sports, Arts and Management Engineering (ICESAME 2018). Atlantis Press, 2018.

Dinamika dan Aktivisme Filantropi Islam dalam Pemberdayaan Masyarakat. Yogyakarta: Litera (2018). ."Aktivisme Pemberdayaan Masyarakat dan Institusionalisasi Filantropi Islam di Indonesia." Islamadina 13.2 (2014): 23-44.

Muhammadiyah, Dewan Syariah LAZIS. "Pedoman Zakat Praktis." Suara Muhammadiyah, Yogyakarta (2004).

Suwandi, 2015. Disentralisasi Fiskal dan Dampaknya terhadap Pertumbuhan Ekonomi, Penyerapan Tenaga Kerja, Kemiskinan, dan Kesejahteraan di Kabupaten/Kota Induk Provinsi Papua. Yogyakarta: Deepublish. Undang-Undang (UU) Nomor 23 tahun 2011 tentang Pengelolaan Zakat 